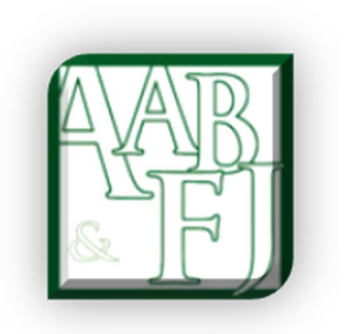

\title{
Environmental Initiatives and Disclosures by Large Companies: The Views of Investors
}

\author{
Salina Siddique ${ }^{1}$ and Nicola Sciulli $^{2}$
}

\begin{abstract}
The purpose of this paper is to explore investors' perspectives on the environmental initiatives and disclosure strategies of large firms. Obtaining such viewpoints is important because, as signaling theory suggests that investors' perspectives are one of the contributory factors in determining organisational strategies for environmental initiatives and disclosures. We used a web-based questionnaire of a group of investors. We put forward a hypothetical case study that raised financial versus environmental consequences of safe waste disposal initiatives for a large company. The findings revealed that a majority (90.21 per cent) of the investors preferred a pro-environmental strategy for waste disposal when a large firm in an environmentally sensitive sector is responsible for polluting the regional water resource. Our findings concluded that investors expect a high quality of environmental disclosures from larger firms as opposed to smaller firms. This study contributes to the literature by presenting investors perspective on firms' environmental decisions using a hypothetical case study.
\end{abstract}

JEL classification: $\mathrm{L} 21$

Keywords: environmental initiatives, environmental disclosures, investors, dilemma

\footnotetext{
${ }^{1}$ Corresponding author. College of Business, Metropolitan State University of Denver, USA

Phone: 303-615-0479, Office: AD 500C, Email: ssiddiqu@msudenver.edu

${ }^{2}$ Victoria University Business School, PO Box 14428, Melbourne, VIC 8001, Victoria, Australia Phone +61 (3) 9919 4424, Email: Nick.Sciulli@,vu.edu.au
} 
Siddique \& Sciulli | Environmental Initiatives and Disclosures by Large Companies

\section{Introduction}

Regardless of the continuing debate surrounding anthropogenic climate change, environmental management is an important strategic issue for companies. However, managers often face a dilemma in making environmental management decisions as the outcome of such decisions are often uncertain (Lee \& Klassen, 2016). Environmental management initiatives require immediate financial investment while the environmental remediation expected from such initiative often takes time to materialise. Therefore, a managers' dilemma may revolve around the choices of individual versus competitors' action, economic versus environmental preferences and short-term versus long-term outcomes (Siddique \& Sciulli 2018; Chinda 2016). Further, research studies have established that among other factors, such as institutional pressure, existing laws and regulations, cultural factors and firm size are important factors in determining environmental initiatives and disclosures (Brammer \& Pavelin, 2008; Rover et al., 2015; Comyns, 2016).

A number of research studies demonstrated that large firms, especially those in environmentally sensitive sectors, provide more environmental disclosures than their smaller counterparts (Brammer \& Pavelin, 2008; Prado-Lorenzo et al., 2009; Tagesson et al., 2009; Da Silva Monteiro \& Aibar-Guzmán, 2010; Galani et al, 2012; Andrikopoulos \& Kriklani, 2013; Bhattacharyya, 2014; Eleftheriadis \& Anagnostopoulou 2015). Because of the widespread operational impact of large firms on environmental well-being, these firms draw attention from a wide range of stakeholders, including investors, consumers, government and environmental lobby groups. Therefore, in order to lessen public pressure, they tend to provide disclosures on the environmental aspect of their business activities (Yao and Yang, 2017). The strategy of providing environmental disclosures in annual reports signals transparency as it enables investors to make informed decision about "managers' sustainability decisions and actions" (Ahmadi \& Bouri, 2017, p. 491). Further, large firms tend to have excess financial resources to spend on pro-environmental initiatives disclosures (Eleftheriadis \& Anagnostopoulou 2015) and to increase credibility, the environmental disclosures should report on the impact of firms' operation on the natural environment including air, water and soils in a measureable and verifiable manner (Patten and Zhao, 2014; Michelon et al., 2015).

Whether a firm is able to secure a financial gain from assuming environmental management initiatives and providing quality environmental disclosures, is found to be inconclusive in prior research. Yadav et al. (2016) suggested that firms' financial performance is positively associated with the high quality of environmental disclosures. Antonis et al. (2014) reported that providing disclosures on environmental initiatives could alleviate risk and provide a competitive advantage to firms. Conversely, other studies found that the environmental initiative expenditure might negatively affect a firm's financial performance (Richardson \& Welker, 2001). Therefore, the environmental management may reduce the future risk of incurring environmental fines/clean-up costs, enhance the reputation of organisations and endorse competitive advantage in the long run.

Conversely, it may have a negative impact on firms' short-term financial performance via immediate cash outlays, which may act as a disincentive to potential investors (Yadav et al., 2016). Such a situation may put managers into a dilemma of whether they should undertake environmental initiatives and provide quality environmental disclosures in the annual reports. Siddique \& Sciulli (2018) concluded that such managerial dilemmas are supported by investor' expectations as their findings evidenced that the majority of the investors were uncertain about whether a small firm should undertake pro-environmental strategies. This current paper builds on from Siddique \& Sciulli (2018) and turns the attention to the investors' perspectives on environmental initiatives and environmental disclosure of large firms. Therefore, the first objective of this paper is to explore investors' preferences to environmental initiatives and disclosure decisions for a large firm in a given context. Second, we also sought investors' views on the extent, they required small and large companies to provide environmental disclosures. Such a comparison is important, as it would offer explanations as to why the extent and the quality of environmental disclosures in corporate reports vary between small and large firms from an investors' point of view (Rover et al., 2015; Comyns, 2016). 
Further, the environmental decision dilemma revolves around the notion of putting forward the expectation of self-interest driven groups, such as investors, over socially desirable outcomes when exploiting the natural environment. Being a common good, the natural environment tends to be subject to commoners' tragedy. Environmental resources can be over-used or abused by corporations for their own benefit that may lead to significant degradation of natural resources, including soil, water and natural habitat (Scalet, 2006). Alternatively, while ensuring environmental well-being by corporations make all relevant parties, including the community eventually better off, it comes at the expense of financial costs and hence, affects shareholders' return. Hence, it is argued that being an important stakeholder group, investors' expectations often influence managers' decision-making process with regard to environmental management. Therefore, the third objective of this paper is to seek out whether investors are willing to favour pro-environmental initiatives even if they reduce the financial return of their investment in the short-run.

The results of our study suggest that investors consider contextual factors, such as specific environmental impact and ramifications, while expecting large firms to take pro-active environmental measures. The study has important practical and theoretical contributions. It demonstrates investors' expectations of environmental management decisions in a given context, and hence, have implications on the development of policies and guidelines by organisations and regulatory authorities. Further, the findings of this research would add investors' perspective to the body of literatures suggesting a positive association of firm size with the quality of environmental disclosures (Brammer \& Pavelin, 2008; Ahmadi \& Bouri, 2017).

The remainder of the paper is organised as follows. The next section provides a discussion on the empirical research in developing the context of the hypothetical case study and construction of the questionnaire with the theoretical underpinnings. This is followed by sections three and four explaining the method and presenting the research findings. The final section discusses the overall conclusions with the implications for literature, practice, limitations and areas for future research.

\section{Literature Review, context and development of the questionnaire}

\subsection{Literature Review}

Prior literature identified firm size and industry affiliation to be the most common determinant for environmental initiatives and disclosures (Brammer \& Pavelin, 2008; Branco Rodrigues, 2005; Branco et al., 2014; Dias et al., 2018). The literature suggests that environmentally sensitive sectors, such as mining sectors are under frequent scrutiny by public and regulatory authorities because of their potential destructive and long-lasting effect on the environment (Kemp et al., 2012; Lodhia and Hess, 2014; Mudd, 2010). Hence, several mining companies have been adopting sustainable initiatives and use voluntary corporate social responsibility disclosures as a mechanism to restore their environmental reputation (Dashwood, 2013). A 2017 KPMG survey reported that globally, the Oil \& Gas sector, including the mining sector take a leadership role over other business sectors in reporting corporate responsibility disclosures (KPMG, 2017). Dashwood (2013) argued that institutional norms and managerial preferences are key variables that contribute to the enhanced sustainable practices in the mining industry. A recent content analysis-based study undertaken by Lee (2017) demonstrated that the size of firms influences the extent and the quality of environmental disclosures in public reports. Hence, the context of the hypothetical case study developed for this study is based on a specific environmental practice of a large company from an environmentally sensitive sector, that is, the mining sector. In this paper, we intend to analyse the preferences of investors, being a key stakeholder group, regarding corporate environmental practices of the mining industry.

The impact of mining operations depends on a range of factors such as the geological factors, extraction method, nature and amount of waste production and their disposal methods (Ranängen et al., 2014). The consequences of waste disposal are considered as one of the significant sources of environmental pollution as many of these pollutants are toxic and can cause significant damage to the environment. Further, the harmful impact of some pollutants (e.g., copper, mercury) take a longer period of time to become visible, 
Siddique \& Sciulli | Environmental Initiatives and Disclosures by Large Companies

often after the mining sites are abandoned following the conclusion of the mining operations ( Sözen et al., 2017). Hence, in this project, we prepared a questionnaire that sets out a hypothetical case study portraying waste disposal practice, initiatives and subsequent disclosures of a large company in the context of the mining industry. Due to the commoners' tragedy surrounding the natural environment and the inconclusive relationship between environmental management and positive financial outcome, managers often face a dilemma of whether to invest in environmental initiatives. Other factors come into play to accentuate such a dilemma. For example, the time lag between the occurrence of waste disposal and the visibility of the impact of such disposal often prompts managers to ignore the necessity of undertaking any environmental initiatives. Given this context, the following hypothetical case study is prepared that raises the issue of a considerable negative environmental impact of a firm and the environmental versus financial consequences of managerial decision.

\subsection{Context and development of the questionnaire}

Explanation of the hypothetical case study and associated theories

Hypothetical Case Study:

Big Ltd is a large coal mining company that operates in a number of regions in Australia and overseas. Recently, it commenced operations in the headwaters region of a river into which it dumps toxic waste. No immediate detrimental impact is obvious in that region as the waste is carried away by the current. However, it is envisaged that over a period the waste will accumulate downstream. This will adversely affect the water quality and cause contamination of the fish stock and vegetation in that region. This will also result in negative media attention and may increase regulation relating to clean-up costs and prevent the company from using the river in the future. Adoption of alternate safe waste disposal methods by the company will prevent all these future negative impacts but will substantially increase the company's current operating costs and decrease the return to shareholders.

Considering this situation, the managers of Big Ltd may choose any of the following four choices:

A. Do not expend resources on safe waste disposal methods BUT disclose the impacts of waste disposal in the annual report.

B. Expend resources on safe waste disposal methods AND disclose the impacts of safe disposal in the annual report.

C. Neither expend resources on safe waste disposal methods nor disclose the impact of waste disposal in the annual report.

D. Expend resources on safe waste disposal methods BUT do not disclose the impact of safe disposal in the annual report.

The hypothetical case study depicts that the large coal mining company would attract government and/or non-government (media and environmental lobby groups) scrutiny because of its poor waste disposal practice (Hahn \& Kühnen, 2013). However, any attempt to address such an issue would result in substantial financial outlays and thereby adversely affect its short-term operating profit and shareholder returns. The remoteness of any visible impact (both in place and time) from poor environmental practices, as presented in the hypothetical case study, would bring the managers an additional dilemma in making decisions about adopting necessary environmental measures.

Hence, the matter of concern raised in the hypothetical case study is, whether to undertake environmental initiatives in order to reduce the environmental risk resulting directly from the company's operation or to overlook such a risk in order to maintain current financial performance. Further, the hypothetical case study 
incorporates a decision to 'disclose' or 'not disclose' where such decisions may or may not rely on the undertaking of safe waste disposal initiatives. Specific disclosures on pollution impacts and initiatives would promote transparency and credibility (Bird \& Smith, 2005) and hence, competitiveness (Connelly et al., 2011). Alternatively, information about negative environmental impacts is unlikely when such impacts are assumed unobservable by the public or when the costs of providing information are more than their benefits (Connelly et al., 2011).

In this paper, we presented the findings of the three questions: the first question is related to the hypothetical case study. The second question relates to firm size and disclosures, and the third question is about the willingness to adopt environmental initiatives at the expense of short-term economic benefit. The questions are provided below with their underlying theory.

\section{Question 1: environmental versus financial consideration}

The first question required the investors to rank the four choices under the hypothetical case study according to their preferences as first, second, third and fourth. The investors were presumed to consider the environmental versus economic consequences of each choice and rank them as per their ideological positions as pro-environmental or pro-financial or neither.

However, negative information about the organisational activities may also be communicated as 'an unintended consequence of insiders' action' (Connelly et al., 2011, p. 45). Providing negative information may also 'serve as a powerful means of guaranteeing honesty' (Bird \& Smith, 2005, p. 223). Therefore, Choice A, which is suggestive of providing disclosure of waste impacts even in the absence of undertaking preventive initiatives, is contained in the hypothetical case study. The decision to provide disclosures over non-disclosures by the entity, irrespective of the deployment of any safe disposal method, indicates an ecocentric belief (Bird \& Smith, 2005, p. 223).

Adopting and maintaining innovative and safe waste disposal method and providing relevant disclosures result in a substantial increase in capital and operating expenditure. Hence, as signaling theory suggests, managers need to decide whether to disclose information publicly and what to disclose. The theory predicts that managers communicate positive information to portray the firms' positive attributes (Connelly et al., 2011). Disclosures of any preventative measures indicate preparedness for future risks and, hence, signal competitive advantage. Therefore, disclosures are likely when managers undertake safe waste disposal initiatives. This notion is incorporated in Choice B.

Alternatively, waste disclosures are unlikely if: 1) the harmful waste impacts are deemed to be unobservable to the stakeholders; or 2) if the cost of providing waste disclosures outweighs their benefits (Connelly et al., 2011). These two viewpoints justify the inclusion of Choices $C$ and $D$, respectively, in the hypothetical case study.

Choice B denotes a dominant pro-environmental strategy because it favors investment in safe disposal methods and subsequent disclosures of relevant impacts. Alternatively, Choice $\mathrm{C}$ suggests neither investment in, nor disclosures of, waste management activities and constitutes a dominant pro-financial strategy. This choice advances the idea of avoiding the costs of undertaking safe waste management initiatives and disclosures rather than promoting environmental well-being. However, Choice A (disclosing the impact without undertaking initiatives) and $\mathrm{D}$ (undertaking initiatives without providing disclosures) do not constitute a dominant pro-environmental or pro-financial strategy.

\section{Theoretical underpinnings for analysis of preference ranking}

The choices (A, B, C and D) presented under the hypothetical case study follows the Prisoner dilemma (PD) model of Game theory that is applied in Siddique \& Sciulli (2018). Game theory is a study of decisionmaking in a competitive environment where two or more players make choices that potentially affect the 
Siddique \& Sciulli | Environmental Initiatives and Disclosures by Large Companies

interest of others (Deng et al., 2014). The game theory is used to formulate a mathematical matrix for analysing the preference rankings and identifying dominant strategies. However, in this hypothetical case study, the PD model under game theory could not be applied directly as there was only one active player, 'investors'. In this case, a pseudo-game theoretic notion was applied in a modified way. In a pseudo-game theoretic model, one player leads an action, followed by others (Neshat \& Amin-Naseri, 2014). Instead of using two players, in this case, only one player is active in making both decisions: undertaking safe disposal initiatives and making public disclosures. Therefore, in this case, the cost-benefit trade-offs of the environmental versus financial dilemma of undertaking environmental initiatives was paired with disclosure decisions. A choice-matrix was prepared to determine whether a preference ranking revealed a dominant strategy. This is presented in Table 1.

Table 1: Matrix for identifying a dominant strategy under a pseudo-game theoretic notion

\begin{tabular}{|c|c|c|c|}
\hline \multirow{4}{*}{$\begin{array}{l}\text { Safe } \\
\text { disposal } \\
\text { initiatives }\end{array}$} & \multicolumn{3}{|c|}{ Public disclosures of waste disposal } \\
\hline & & Disclose (Pro-environmental) & Do not disclose (Pro-financial) \\
\hline & $\begin{array}{l}\text { Undertake } \\
\text { initiatives } \\
\text { (Pro- } \\
\text { environmental) }\end{array}$ & $\begin{array}{l}\text { Choice B: } \\
\text { Both 'undertake initiatives' and } \\
\text { 'disclose' (i.e., spend resources on } \\
\text { safe waste disposal method and } \\
\text { provide disclosures) }\end{array}$ & $\begin{array}{l}\text { Choice D } \\
\text { 'Undertake initiatives' only (i.e., spend } \\
\text { resources on safe waste disposal } \\
\text { method only but do not provide } \\
\text { disclosures) }\end{array}$ \\
\hline & $\begin{array}{l}\text { Do not } \\
\text { undertake } \\
\text { initiatives } \\
\text { (Pro-financial) }\end{array}$ & $\begin{array}{l}\text { Choice A: } \\
\text { Do not 'undertake initiatives' or } \\
\text { spend on safe disposal initiatives } \\
\text { but provide specific disclosures }\end{array}$ & $\begin{array}{l}\text { Choice C: } \\
\text { Neither 'undertake initiatives' for safe } \\
\text { disposal method nor provide } \\
\text { disclosures }\end{array}$ \\
\hline
\end{tabular}

Because the decision to 'undertake initiatives' is focused on ensuring environmental well-being at the expense of financial outlays, it served as the main determinant for a 'pro-environmental' strategy. Hence, 'undertaking initiatives' was positioned as the row player in the matrix. Alternatively, the decision to make 'public disclosure' was regarded as the column player, as such decisions act as an additional determinant towards a 'pro-environmental' strategy. Favouring the undertaking of safe waste disposal methods and/or providing disclosures constitutes a 'pro-environmental' strategy. Alternatively, rejecting either initiative for safe disposal methods or disclosure represents a 'pro-financial' strategy.

Therefore, Table 1 indicates that management action is deemed to be 'pro-environmental' if it undertakes initiatives for safe disposal irrespective of providing disclosures (which is Choice B and D). Alternatively, management action is presumed to be pro-financial if it does not undertake safe disposal methods (Choice A and C).

The analytical process for identifying the dominant strategy of a respondent follows the method suggested by Pellikaan and Veen (2002). The process involved two steps:

Step 1 assigns scores of 1 to 4 in a highest (4) to lowest (1) order to the choices in the choice-matrix according to the preference ranking expressed by the respondent. For example, in Question 1, if a respondent expressed a preference ranking BDCA (which indicates, first preference $\mathrm{B}$ and the last preference $\mathrm{A}$ ), the scores to the choices in the choice-matrix would be assigned as: 4 for $\mathrm{B}, 3$ for $\mathrm{D}, 2$ for $\mathrm{C}$ and 1 for A. Step 2 calculates the total score for each row in the matrix. The strategy (proenvironmental/pro-financial) indicated in a row would be considered the dominant strategy if that row had a maximum value. Alternatively, if both rows in the matrix have the same value, the outcome of the preference ranking would be regarded as a 'no maximising rule'. The process of assigning values for identifying the dominant strategies are further explained in the findings section. 


\section{Question 2: Investors preference for the quality of environmental disclosures for small and large companies}

This question is set out to explore whether investors' preference for the level of the quality of environmental disclosures varies among the small and large companies. Environmental initiatives and disclosures have costly financial implications and hence, often become a source of conflicts among the stakeholders group such as shareholders, consumers and environmental activists. However, based on the investigation of 21,030 US firms, Benlemithlih \& Bitar (2018) found that the environment components of corporate social responsibility reporting are directly related to investment efficiency. This question would obtain direct evidence of investors' preferences on the quality of corporate environmental disclosures and make an important contribution to the existing body of literature.

Firm size is defined in a number of ways in the literature: by market capitalisation (de Villers et al., 2014; Brammar \& Pavelin, 2008), number of employees (Tilley, 2000), and annual revenues (Gallo \& Christensen, 2011 ) combined with number of employees (Coppa \& Sriramesh, 2013; Perrini et al., 2007; Xie et al., 2014; Buonanno et al., 2005). In this study, the difference between small and large companies was indicated by annual revenue. A company was regarded as small if its annual revenue was less than $\$ 25$ million, otherwise, it was large. This cut-off point coincides with the annual revenue criteria of the small vs large company definition provided in the Australian Corporations Act 2001, s. 45 A. Five levels of pollution disclosures along an increasing hierarchy of quality (from general statements towards disclosures that are more specific) were provided. Such a hierarchy is guided by the quality criteria used in the studies that investigated the quality of corporate social and environmental disclosures (Cormier \& Magnan, 2015; Wong \&Millington, 2014; Beck et al., 2010; Brammer \& Pavelin, 2008; Lee, 2015). Additional information, such as an example for each level of disclosure and the occurrence of the possible cost of preparation of such disclosure was also provided. The five levels of information are presented in Table 2 .

Table 2: Disclosure of information based on quality hierarchy

\begin{tabular}{|l|l|}
\hline Levels & Description of the levels \\
\hline Level 1 & Statutory declaration that the company is complying with the existing environmental laws \\
\hline Level 2 & $\begin{array}{l}\text { Level 1 disclosure plus a general statement regarding the company's exposure to potential } \\
\text { regulatory risks. For example, 'Our operations are subject to potential laws and regulations } \\
\text { governing environmental protection, rehabilitation and closure'. }\end{array}$ \\
\hline Level 3 & $\begin{array}{l}\text { Level 1 \& 2 disclosures plus a general statement on the impact of the company's operations on } \\
\text { the environment. For example, 'Our operations, by their nature, have the potential to pollute the } \\
\text { natural environment. We run programs to control such impacts'. }\end{array}$ \\
\hline Level 4 & $\begin{array}{l}\text { Level 1, 2 \& 3 disclosures plus specific disclosures on pollution. For example, the amount, } \\
\text { nature (toxic/non-toxic), measurable targets and performance against the targets. [Note: } \\
\text { companies need to implement appropriate information systems at additional costs to produce } \\
\text { these disclosures]. }\end{array}$ \\
\hline Level 5 & $\begin{array}{l}\text { Level 1, 2, 3 \& 4 disclosures plus an independent environmental assurance report. [Note: } \\
\text { companies need to employ environmental auditors at additional costs to produce such a report.] }\end{array}$ \\
\hline
\end{tabular}

The investors were asked to indicate their opinion by selecting either 'yes' or 'no' in the drop-down menu ascribed for each level of disclosure for both small and large companies. The aim was to obtain evidence about the extent to which investors expect quality disclosures from small and large companies.

\section{Question 3: Willingness to sacrifice financial interest over environmental concern}

The question of immediate financial outlays triggered by the adoption of safe disposal initiatives was highlighted in the hypothetical case study. The case also indicated that such financial outlays might reduce the return to shareholders and hence, create a dilemma for the companies' managers. Thus, the last question sought to examine whether investors were still willing to invest or hold shares in a company knowing that 
Siddique \& Sciulli | Environmental Initiatives and Disclosures by Large Companies

its expenditure on safe disposal initiatives would reduce its short-term profit (e.g. in two years). The Investors were requested to indicate their preference as 'yes' or 'no'.

\section{Method:}

\subsection{Sample}

The sample of the survey comprises the members of an investment firm known as Morningstar Australasia Pty Ltd (Morningstar) which has a large membership base (10,000 fee-paying members) who were deemed to be current and prospective investors in Australian and overseas share markets. $85 \%$ of the sample completing the survey were male, $75 \%$ held a university degree, $80 \%$ managed their investments personally and via investment funds.

\subsection{Survey method}

A web-based survey was undertaken by accessing the website of Morningstar Australasia Pty Ltd (Morningstar). The approach is similar to the methods used by Deegan \& Rankin (1997) and de Villiers \& van Staden (2011) in that the samples used in these studies were also selected from the members of an association of shareholders.

One limitation associated with the survey was that various members of the population in the sample cannot be determined. Hence, the problem of restricting the exposure of the survey to its intended target population was expected. This issue was mitigated by taking the following steps: (i) the survey link is included in an article addressing environmental concerns of the resource sector companies published in the "Stock" section of the website; (ii) inserting a specific investment question in the demographic section of the questionnaire; and (iii) enabling the survey instrument to block multiple completions by the same person using an internet protocol address blocker function.

Being an unrestricted, self-selected web survey, it is also associated with the non-coverage and nonresponse bias that is offset by applying a statistical method - namely, raking ratio estimation. The raking ratio estimation method is defined as "a post-stratification procedure for adjusting the sample weights in a survey so that the adjusted weights add up to a known population" (Cohen, 2008, p. 3). This method is applied where a sample is taken from a segment of a target population "in proportions that do not match the proportions of those segments in the population itself" (Battaglia et al., 2004, p. 4740). The method improves the relationship between the sample and the population by adjusting the sampling weights of different variables in the sample so that "the marginal totals of the adjusted weights on specified characteristics agree with the corresponding totals for the population" (Battaglia et al., 2004, p. 4740). Raking ratio estimation is a common method used by researchers to compensate for non-response and noncoverage from known population values (Cervantes \& Brick, 2008; Katlon \& Cervantes, 2003).

PD model of Game theory is used to formulate a choice matrix as explained in the previous section that provided the required analytical framework (Table 1) to analyse investors' preferences for the safe disposal initiatives and disclosures. The process of developing the matrix replicates the method provided in Pellikaan and Veen (2002) where the authors devised such a matrix to explore the behaviour of a group of households with respect to their waste disposing method. Prisoners' dilemma is illustrated in Scalet (2006) as an example of how economic institutions such as corporations face challenges in policy making when individual interest does not align with the efficient outcome desired collectively in the society. The misalignment results because a self- interested agent often finds it hard to sacrifice economic interest for achieving a better outcome from a collective point of view. The PD model of Game theory is also used in experimental simulation studies in marketing research (Watkins \& Hill, 2005), ethical social norm dilemma studies (James and Cohen, 2004; White, 2009; Ostrom, 2000; Arce, 2010) discussion papers and experimental studies in sustainability research (Robèrt, \& Broman, 2017; Lorenzo, 2007). In this study, the 
PD model of Game theory is used to analyse the survey findings of investors' preference for safe disposal initiatives and disclosures and hence, makes a methodological contribution to corporate environmental research.

\section{Findings:}

The number of investors that commenced the survey was 198; however, only 194 provided a complete response to Question 1. The ranking of the four choices given under the hypothetical case study as per the Investors' preferences is summarised in Table 3.

Table 3: Weighted percentages (\%) and the higher and lower limits of the range at a $95 \%$ confidence level of the preference ranking

\begin{tabular}{|c|c|c|c|c|c|c|c|}
\hline & & & \multicolumn{4}{|c|}{ Preference ranking } & \multirow[b]{2}{*}{ Row total } \\
\hline Choices & & & $1 \mathrm{st}$ & 2nd & 3rd & 4th & \\
\hline \multirow[t]{3}{*}{ A } & \multirow[t]{3}{*}{ Disclose only } & Percentage $(\%)$ & 1.05 & 8.02 & 67.28 & 21.63 & $97.98^{*}$ \\
\hline & & Upper limit & 2.52 & 12.5 & 74.63 & 28.26 & \\
\hline & & Lower limit & 0 & 3.54 & 59.93 & 14.99 & \\
\hline \multirow[t]{3}{*}{ B } & \multirow{3}{*}{$\begin{array}{l}\text { Undertake } \\
\text { initiatives and } \\
\text { disclose }\end{array}$} & Percentage $(\%)$ & 92.99 & 2.68 & 1.76 & 0.55 & 97.98 \\
\hline & & Upper limit & 97.01 & 5.01 & 4.34 & 1.63 & \\
\hline & & Lower limit & 88.97 & 0.35 & 0 & 0 & \\
\hline \multirow[t]{3}{*}{$\mathrm{C}$} & \multirow{3}{*}{$\begin{array}{l}\text { Neither undertake } \\
\text { initiative nor } \\
\text { disclose }\end{array}$} & Percentage $(\%)$ & 3.93 & 3.91 & 19.71 & 70.43 & 97.98 \\
\hline & & Upper limit & 7.23 & 7.12 & 26.21 & 77.7 & \\
\hline & & Lower limit & 0.63 & 0.70 & 13.21 & 63.17 & \\
\hline \multirow[t]{3}{*}{$\mathrm{D}$} & \multirow{3}{*}{$\begin{array}{l}\text { Undertake } \\
\text { initiative only }\end{array}$} & Percentage $(\%)$ & 0 & 83.38 & 9.23 & 5.37 & 97.98 \\
\hline & & Upper limit & 0 & 89.25 & 13.62 & 9.38 & \\
\hline & & Lower limit & 0 & 77.5 & 4.84 & 1.36 & \\
\hline
\end{tabular}

*194 out of the 198 Investors who started the survey responded to this question and hence the percentage of the row total is calculated as $97.98 \%(194 / 198)$.

The survey data presented in Table 3 are adjusted for raking weight calculated by the raking estimation method and shown in the form of percentages and the upper and lower limit of the range at the $95 \%$ confidence level respectively.

Given the context described in the hypothetical case study, the choice of undertaking a safe waste disposal method and disclosing the impact of safe disposal in the annual report (choice B) is indicated as the first preferred choice of action (92.99 per cent, Table 3 ). In contrast, taking no action and providing no disclosure (Choice C) was found to be the least favoured choice (70.43 per cent, Table 3). It is noteworthy that undertaking safe disposal initiatives without providing any disclosure (choice D) was not regarded as the first choice by any of the Investors. This is probably because the investors were not likely to rule out the potential of such disclosures in alleviating the risk and gaining competitive advantage.

However, Table 3 also highlights that Choice D (83.38 per cent) was preferred over Choice A (67.28 per cent). This suggests that the investors were concerned about the observability of the pollution impact of the unsafe waste disposal method. Further, the Investors may have considered the additional risk of providing disclosure of such impacts without taking any prevention scheme. Therefore, undertaking initiatives even without corresponding disclosures (Choice D) was favoured over providing impact disclosures without undertaking initiatives (Choice A).

While the results portrayed in Table 3 provide insights regarding the investors' preferences about an individual choice of action, such results do not reveal a dominant strategy deliberated by a respondent while 
Siddique \& Sciulli | Environmental Initiatives and Disclosures by Large Companies

ranking the choices of action. A respondent may have a dominant strategy of either 'pro-environmental' or 'pro-financial'. Alternatively, they may have no dominant strategy, which can be designated as 'no maximising rule'. In order to gain an understanding of the Investors' preferred strategy, the preference ranking of each respondent is further analysed and interpreted by applying the PD model of game theory as follows.

In order to perform the preference ranking across the four choices of action (A, B, C and D), the investors were expected to follow a strategy based on an environmental versus financial focus. The cost-benefit tradeoff of undertaking environmental initiatives was paired with the disclosure decision in the case study.

Because there were four choices through which preference ranking could be made, a respondent could choose any of the $24(4 \times 3 \times 2 \times 1)$ outcomes. The identification of whether an outcome indicates a dominant strategy (of pro-environmental or pro-financial) or a no maximising rule was determined by inserting scores in the outcome matrix (Table 1). For each row player's response (i.e., their choice in the hypothetical case study), a payoff matrix was prepared by allocating the highest to lowest score (from 4 to 1) for each preferred outcome according to the preference ordering. The scores were aggregated for a row player in the payoff matrix to determine the dominant strategy in a preference ordering as reported by a respondent.

The choices of A, B, C and D are designated as follows:

A. Do not undertake initiatives but provide disclosure: pro-financial

B. Undertake initiatives and provide disclosures: pro-environmental

C. Neither undertake initiatives and nor provide disclosures: pro-financial

D. Undertake initiatives and do not provide disclosures: pro-environmental

Therefore, the necessary conditions required for a preference ranking to indicate a dominant proenvironmental strategy are specified as to where choice $\mathrm{B}$ is preferred to ('>' is used to indicate 'is preferred to') A (written as $\mathrm{B}>\mathrm{A}$ ) and choice $\mathrm{D}>\mathrm{C}$. For a dominant pro-environmental strategy, the necessary condition in a pair-wise ranking should be 'B $>\mathrm{A}$ and $\mathrm{D}>\mathrm{C}$ '. The characteristic of this strategy is the allocation of higher scores in the row total of 'undertake initiatives' in Table 1 than that of 'do not undertake initiatives'. Thus, the six preference rankings - BADC, BDAC, BDCA, DBAC, DBCA and DCBA were identified as dominant pro-environmental strategy.

The necessary conditions required by a preference ordering to reveal a dominant pro-financial strategy is specified as a pair-wise ranking where ' $\mathrm{C}>\mathrm{D}$ and $\mathrm{A}>\mathrm{B}$ '. Such conditions ensure that the row total of 'do not undertake initiatives' is higher than that of 'undertake initiatives' row in Table 1 . Therefore, the six preference orderings $\mathrm{ABCD}, \mathrm{ACBD}, \mathrm{ACDB}, \mathrm{CABD}, \mathrm{CADB}$ and $\mathrm{CDAB}$ were considered to have a dominant pro-financial strategy.

The remaining 12 out of the 24 possible preference orderings belonged to the 'no dominant strategy' category, with pair-wise ranking conditioned as either ' $\mathrm{B}>\mathrm{A}$ and $\mathrm{C}>\mathrm{D}$ ' $(\mathrm{BACD}, \mathrm{BCAD}, \mathrm{BCDA}, \mathrm{CBAD}$, CBDA and CDBA) or ' $\mathrm{A}>\mathrm{B}$ and $\mathrm{D}>\mathrm{C}^{\prime}$ (ABDC, $\mathrm{ADBC}, \mathrm{ADCB}, \mathrm{DABC}, \mathrm{DACB}$ and $\left.\mathrm{DCAB}\right)$. For these preference rankings, the row totals for both rows in the choice-matrix shown in Table 1 are the same. Hence, Investors did not indicate a dominant strategy.

The number and the percentage of the investors choosing a particular preference ranking with the corresponding strategies are summarised in Table 4. 
The first two columns of Table 4 present the 24 possible preference rankings and their corresponding strategies, respectively. The strategies are designated as 'pro-environmental', 'pro-financial' or 'no dominant strategy'. The number of investors indicating a particular strategy are summarised in the next three column of the Table 4. The last two columns present the total number of each preference ranking and their percentages.

Table 4: Dominant Strategy revealed by the Investors

\begin{tabular}{|l|l|c|c|c|c|c|}
\hline $\begin{array}{c}\text { Preference } \\
\text { Ordering }\end{array}$ & $\begin{array}{c}\text { Strategies as per } \\
\text { preference ordering }\end{array}$ & $\begin{array}{c}\text { Pro- } \\
\text { environmental }\end{array}$ & $\begin{array}{c}\text { Pro- } \\
\text { financial }\end{array}$ & $\begin{array}{c}\text { No dominant } \\
\text { strategy }\end{array}$ & Number & $\begin{array}{c}\text { Row } \\
\text { Percentage }\end{array}$ \\
\hline ABCD & Pro- financial & 0 & 0 & 0 & 0 & $0.00 \%$ \\
\hline ABDC & No dominant strategy & 0 & 0 & 1 & 1 & $0.52 \%$ \\
\hline ACBD & Pro-financial & 0 & 1 & 0 & 1 & $0.52 \%$ \\
\hline ACDB & Pro-financial & 0 & 0 & 0 & 0 & $0.00 \%$ \\
\hline ADBC & No dominant strategy & 0 & 0 & 0 & 0 & $0.00 \%$ \\
\hline ADCB & No dominant strategy & 0 & 0 & 0 & 0 & $0.00 \%$ \\
\hline BADC & Pro-environmental & 7 & 0 & 0 & 7 & $3.61 \%$ \\
\hline BACD & No dominant strategy & 0 & 0 & 5 & 5 & $2.58 \%$ \\
\hline BCAD & No dominant strategy & 0 & 0 & 0 & 0 & $0.00 \%$ \\
\hline BCDA & No dominant strategy & 0 & 0 & 6 & 6 & $3.09 \%$ \\
\hline BDAC & Pro-environmental & $\mathbf{1 4 0}$ & 0 & 0 & 140 & $\mathbf{7 2 . 1 6 \%}$ \\
\hline BDCA & Pro-environmental & $\mathbf{2 8}$ & 0 & 0 & 28 & $\mathbf{1 4 . 4 3 \%}$ \\
\hline CABD & Pro-financial & 0 & 1 & 0 & 1 & $0.52 \%$ \\
\hline CADB & Pro-financial & 0 & 1 & 0 & 1 & $0.52 \%$ \\
\hline CBAD & No dominant strategy & 0 & 0 & 1 & 1 & $0.52 \%$ \\
\hline CBDA & No dominant strategy & 0 & 0 & 3 & 3 & $1.55 \%$ \\
\hline CDAB & Pro-financial & 0 & 0 & 0 & 0 & $0.00 \%$ \\
\hline CDBA & No dominant strategy & 0 & 0 & 0 & 0 & $0.00 \%$ \\
\hline DABC & No dominant strategy & 0 & 0 & 0 & 0 & $0.00 \%$ \\
\hline DACB & No dominant strategy & 0 & 0 & 0 & 0 & $0.00 \%$ \\
\hline DBAC & Pro-environmental & 0 & 0 & 0 & 0 & $0.00 \%$ \\
\hline DBCA & Pro-environmental & 0 & 0 & 0 & 0 & $0.00 \%$ \\
\hline DCAB & No dominant strategy & 0 & 0 & 0 & 0 & $0.00 \%$ \\
\hline DCBA & Pro-environmental & 0 & 0 & 0 & 0 & $0.00 \%$ \\
\hline Column & & $\mathbf{1 7 5}$ & $\mathbf{3}$ & $\mathbf{1 6}$ & $\mathbf{1 9 4}$ & \\
\hline Cotal & & $\mathbf{9 0 . 2 1 \%}$ & $\mathbf{1 . 5 5 \%}$ & $\mathbf{8 . 2 5 \%}$ & & $100 \%$ \\
\hline Percentage & & & & & 0 & 0 \\
\hline
\end{tabular}

The results presented in Table 4 indicate that 90.21 per cent of the investors answering Question 1 revealed a pro-environmental strategy by ranking the choices with 'undertake initiatives' (B and D) ahead of those with 'do not undertake initiatives' (C and A). In contrast, 8.25 per cent failed to indicate any dominant strategy, and only 1.55 per cent preferred a 'pro-financial' strategy. Two possible reasons may explain why the vast majority of the investors favoured a 'pro-environmental' strategy over 'no dominant' and 'profinancial' strategies. First, the investors might have recognised the potential regulatory risks associated with unsafe waste disposal used by the large mining company mentioned in the hypothetical case study, which 
Siddique \& Sciulli | Environmental Initiatives and Disclosures by Large Companies

is predominantly responsible for polluting the environment. Even though it was indicated that the impact of unsafe waste disposal would take a while to be obvious, the investors may be concerned on a moral or ethical basis about the harmful impact of the unsafe waste disposal.

For Question 2, out of 198 Investors who commenced the survey, 191 (i.e., 96.46\%) provided a complete response. The findings are displayed in Table 5. The investors' views of the quality of disclosures along the hierarchy (from level 1 to 5) for small and large companies is expressed in weight-adjusted percentages with the upper and lower limits at a 95 per cent confidence level.

Table 5: Variation of the investors' expectation of disclosures between small and large companies

\begin{tabular}{|l|l|r|r|r|r|}
\hline $\begin{array}{l}\text { Disclosure } \\
\text { levels }\end{array}$ & & \multicolumn{4}{|c|}{ Size of the companies } \\
\hline & & \multicolumn{2}{|c|}{$\begin{array}{c}\text { Small } \\
\text { companies }\end{array}$} & \multicolumn{2}{c|}{$\begin{array}{c}\text { Large } \\
\text { companies }\end{array}$} \\
\hline & & \multicolumn{1}{c|}{ Yes } & \multicolumn{1}{c|}{ No } & \multicolumn{1}{c|}{ Yes } & \multicolumn{1}{c|}{ No } \\
\hline & & 94.29 & 2.17 & 94.29 & 2.17 \\
\hline & Weight-adjusted percentage (\%) & 96.44 & 4.32 & 96.44 & 4.32 \\
\hline & Upper limit (\%) & 92.14 & 0.02 & 92.14 & 0.02 \\
\hline & Lower limit (\%) & 94.27 & 2.19 & 94.29 & 2.17 \\
\hline & Weight-adjusted percentage (\%) & 96.44 & 4.36 & 96.44 & 4.32 \\
\hline & Upper limit (\%) & 92.10 & 0.02 & 92.14 & 0.02 \\
\hline & Lower limit (\%) & $\mathbf{5 . 4 2}$ & $\mathbf{9 1 . 0 4}$ & $\mathbf{9 4 . 8 3}$ & $\mathbf{1 . 6 3}$ \\
\hline & Weight-adjusted percentage (\%) & 8.76 & 94.38 & 96.70 & 3.51 \\
\hline & Upper limit (\%) & 2.08 & 87.70 & 92.95 & -0.24 \\
\hline & Lower limit (\%) & $\mathbf{1 6 . 1 3}$ & $\mathbf{8 0 . 3 3}$ & $\mathbf{9 2 . 3 9}$ & $\mathbf{4 . 0 7}$ \\
\hline & Weight-adjusted percentage (\%) & 21.55 & 85.74 & 95.27 & 6.96 \\
\hline & Upper limit (\%) & 10.72 & 74.91 & 89.50 & 1.19 \\
\hline & Lower limit (\%) & $\mathbf{7 . 7 9}$ & $\mathbf{8 8 . 6 7}$ & $\mathbf{8 3 . 9 9}$ & $\mathbf{1 2 . 4 7}$ \\
\hline & Weight-adjusted percentage (\%) & 11.64 & 92.53 & 88.83 & 17.31 \\
\hline & Upper limit (\%) & 3.93 & 84.82 & 79.15 & 7.63 \\
\hline & Lower limit (\%) & & & & \\
\hline & & & &
\end{tabular}

The results shown in Table 5 indicate that the expectations of the investors did not vary from large and small companies for level 1 (statutory declaration of compliance with existing regulation) and level 2 disclosures (general environmental risk statement). However, the investors' expectations started to differ from level 3 disclosures (general statement on environmental impact) where they anticipated more disclosures from large companies ( 94.83 per cent) than from small companies (91.04 per cent). Significant differences are observed with regard to both the level 4 (specific environmental disclosures with measurable data) and level 5 disclosures (independent assurance statement). Only 16.13 per cent of the investors indicated 'yes' to level 4 disclosures for small companies as opposed to 92.39 per cent for large companies. For the level 5 disclosures, the investors' expectations from small companies dropped further to 7.79 per cent whereas for large companies it was 83.99 per cent.

These findings suggest that the investors' preferences for environmental disclosures vary from small and large companies along the hierarchy of quality disclosures. While the investors preferred large companies to provide high quality disclosures, they did not expect the same from small companies. Investors might 
have considered the additional cost involved in the preparation of high quality disclosures and, given the resource limitations usually experienced by small companies, they did not expect the small companies to bear an additional cost. Further, the findings reveal that small companies were expected to comply with regulations and hence, provide environmental disclosures if it is required by existing environmental laws such as a statutory compliance statement. General statements including exposure to regulatory risks and impacts of operations on the natural environment are also expected from small companies. However, specific environmental disclosures with regard to the sources, amounts and nature of pollution, measurable targets and performance against such targets were expected of large companies. Further, independent assurance reports of such disclosures were also expected from large companies.

Question 3 also elicited 191 responses (i.e., $96.46 \%$ of all the investors who commenced the survey). The findings for Question 3 are shown in Table 6.

Table 6: Investors willingness to sacrifice short-term profit to support environmental initiatives

\begin{tabular}{|l|c|c|}
\hline Percentage of Investors & \multicolumn{2}{|c|}{ Willingness to sacrifice short-term profit } \\
\hline N & Yes & No \\
\hline Weight-adjusted percentage (\%) & 164 & 27 \\
\hline Upper limit (\%) & $\mathbf{8 1 . 6 8}$ & $\mathbf{1 4 . 7 8}$ \\
\hline Lower limit (\%) & 87.11 & 20.21 \\
\hline
\end{tabular}

The findings reveal that 81.68 per cent of the investors were willing to invest or hold shares in a company, even if its short-term profit is compromised by spending on environmental initiatives.

\section{Conclusion}

Environmental management is a major challenge for mining companies because of the public concern over the potentially harmful impact of its operations on the natural environment and community. While undertaking environmental initiatives helps companies to secure a license to operate, it also comes at the expense of substantial capital investment and maintenance costs. Further, providing disclosures may demonstrate companies' commitment to environmental well-being and hence, enhance their reputation as an environmentally friendly organisation. However, confessing adverse environmental impact of organisational operations may signal risk to investors and discourage existing and prospective shareholders. Hence, the hypothetical case study presented a dilemma of 'environmental initiatives and disclosure' versus 'no initiative and non-disclosure' faced by a large mining company responsible for polluting regional water sources due to its unsafe waste disposal method. Such a dilemma raises the issue of uncertain risks versus the benefits resulting from undertaking safe disposal initiatives and providing related environmental disclosures. Being a primary stakeholder group, investors are surveyed with a view to exploring what strategy they would prefer based on the environmental versus financial dilemma of environmental decisions raised in the hypothetical case study.

The survey findings suggest that, given the context of the hypothetical case study, the majority of the investors (92.99 per cent, Table 4) preferred the company to act pro-environmentally and provide relevant disclosures. Our study extends the work of Siddique \& Sciulli (2018) which sought the investors' preferences for environmental initiatives in the context of small mining companies. Our findings show a sharp contrast with those of Siddique \& Sciulli (2018) which suggested that the investors were indecisive when it comes to decision making for spending resources on environmental initiatives by small companies. In this study, the dominant pro-environmental strategy preferred by the investors would likely be driven by 
Siddique \& Sciulli | Environmental Initiatives and Disclosures by Large Companies

the fact that the company mentioned in the hypothetical case study was individually responsible for polluting the water source, despite the fact that the visible impact was not yet apparent. Hence, the company was more prone to possible community protests and regulatory action that in turn, would culminate in disrupting the company's operation as well as possible financial penalties. These findings support the view raised in Liao (2018) that environmental innovation initiatives serve as an important means for firms to prepare them for potential environmental regulations and help them to demonstrate environmental stewardship as opposed to passive responders.

The findings of this research also demonstrated that the investors' expectations for the quality environmental disclosures varied substantially between the small and large companies. This implies that investors considered the costs of producing quality environmental disclosures (such as the amount and nature (toxic/non-toxic) of waste, disposal methods, measurable targets and performance against the targets). This finding is consistent with the conclusion of the prior works that examined the capital market and publicly available corporate reports and suggested that environmental initiatives/ disclosures has a positive association with firm size that contributed to organisational financial attributes and visibility (Hassan, 2018; Ahmadi \& Bouri, 2017; Yu et. al., 2017). Investors' perspectives obtained in this study also confirm the management view offered in Prasad and Elms (2005) that managers tend to consider environmental pragmatism rather than environmental idealism when providing disclosures. Environmental pragmatism asserts that adopting innovative initiatives enables the prevention of environmental pollution while fostering competitive advantage and maintaining long- term financial payoffs (York, 2009). Such a view is also favoured by the finding that the majority of investors were willing to sacrifice profit at least in the short-term to support pro-active environmental initiatives. This study makes a unique contribution to the literature by exploring the decision-making by investors as opposed to passive market-based research. The findings of this study corroborates the results of the market-based literature (e.g., Yadav et. al., 2016; Endrikat et. al., 2014; Amato and Amato, 2012; Lyon and Shimshack, 2012; Jacob et. al., 2010; Baboukardos, 2018) that found a positive association between corporate environmental initiatives and financial performance.

Most environmental dilemma studies have been undertaken as part of strategic decision-making with special reference to ethics and moral judgement by managers (e.g., Woiceshyn, 2011; Litschka et al., 2011) or in the form of simulation studies (Tanimoto, 2005). Few studies address the investors' dilemma in relation to the mitigation of environmental problems (Aitken, Chapman \& McClure, 2011). This study therefore, makes a unique contribution to methodology by conducting a survey of investors with a questionnaire that highlights environmental versus financial dilemma through a hypothetical case study.

Moreover, this project has important implications for corporate managers and policy-makers. Investors prefer large companies to undertake pollution reduction initiatives and provide relevant disclosures even after considering additional costs associated with those activities. Hence, the managers of large companies, particularly those in the environmentally sensitive sector, should undertake environmental management initiatives and provide relevant and specific environmental disclosures, which in turn, help them to avoid regulatory risks and gain a competitive advantage. The regulatory authorities and policy makers could also consider the results of this study. Since providing environmental disclosures in the publicly available report is largely voluntary, they may consider imposing specific disclosure requirement for companies, providing them with guidelines for safe operational procedures and gathering data related to resource consumption and pollution.

This study has a number of limitations. Being a non-probability based unrestricted self-selected survey, the survey of investors included non-response bias and the possibility of exposure to the unintended Investors. This was overcome by using an appropriate statistical method (estimation and use of raking weight), inserting appropriate demographic questions and designing the survey instrument to block multiple completions. Further, the sample of the survey only represented the existing or prospective members of a 
specific investment fund. Exclusion of other investors who had personal investment in the share markets, as well as institutional investors made the sample less representative. Therefore, the results should be treated with caution for generalisation purposes.

While the current study was based on the responses from investors, the same dilemma-based case study approach can be replicated to investigate the views of managers, regulators, auditors and environmental lobby groups on corporate environmental initiatives and disclosures. This would be an area for future research.

\section{References:}

Aitken, C., Chapman, R., \& McClure, J. (2011). Climate change, powerlessness and the commons dilemma: Assessing New Zealanders' preparedness to act. Global Environmental Change, 21(2), 752-760. doi: https://doi.org/10.1016/j.gloenvcha.2011.01.002

Arce, D. G. (2010). Economics, Ethics and the Dilemma in the Prisoner's Dilemmas. The American Economist, 55(1), 49-57. doi: https://doi.org/10.1177/056943451005500106

Ahmadi, A., \& Bouri, A. (2017). The relationship between financial attributes, environmental performance and environmental disclosure: Empirical investigation on French firms listed on CAC 40. Management of Environmental Quality: An International Journal, 28(4), 490-506. doi: https://doi.org/10.1108/MEQ07-2015-0132

Amato, L. H., \& Amato, C. H. (2012). Environmental Policy, Rankings and Stock Values. Business Strategy and the Environment, 21(5), 317-325. doi: https://doi.org/10.1002/bse.742

Andrikopoulos, A., \& Kriklani, N. (2013). Environmental Disclosure and Financial Characteristics of the Firm: The Case of Denmark. Corporate Social Responsibility and Environmental Management, 20(1), 55-64. doi: https://doi.org/10.1002/csr.1281

Antonis, S., Nikoleta, J., Chrisovaladis, M. and Konstantinos, E. (2014). Trends and determinants of corporate non-financial disclosure in Greece, Journal of Cleaner Production, 68, 174-188. doi: https://doi.org/10.1016/j.jclepro.2013.12.048

Baboukardos, D. (2018). The valuation relevance of environmental performance revisited: The moderating role of environmental provisions. The British Accounting Review, 50(1), 32-47. doi: https://doi.org/10.1016/j.bar.2017.09.002

Battaglia, M., Izrael, D., Hoaglin, D., \& Frankel, M. (2004). Tips and Tricks for Raking Survey Data (aka Sample Balancing). Paper presented at the annual meeting of the American Association for Public Opinion Research, 4740-4745. viewed January 1, 2016, https://www.researchgate.net/publication/228976550

Beck, AC, Campbell, D \& Shrives, PJ. (2010). Content analysis in environmental reporting research: enrichment and rehearsal of the method in a British-German context. The British Accounting Review, 42(3), 207-222. doi: https://doi.org/10.1016/j.bar.2010.05.002

Bhattacharyya, A. (2014), Factors Associated with the Social and Environmental Reporting of Australian Companies, Australasian Accounting, Business and Finance Journal, 8(1), 25-50. doi: https://doi.org/10.14453/aabfj.v8i1.3

Bird, R.B., \& Smith, E.A. (2005). Signaling Theory, Strategic Interaction, and Symbolic Capital. Current Anthropology, 46(2), 221-248. doi: https://doi.org/10.1086/427115

Branco, M.C., Rodrigues, L. (2005). An Exploratory Study of Social Responsibility Disclosure on the Internet by Portuguese Listed Companies. Social Responsibility Journal, 1(1/2), pp.81-90, https://doi.org/10.1108/eb045798

Branco, M.C., Delgado, C., Gomes, S. \& Euge nio, T. (2014), Factors influencing the assurance of sustainability reports in the context of the economic crisis in Portugal. Managerial Auditing Journal, 29(3), pp. 237-252. https://doi.org/10.1108/MAJ-07-2013-0905

Brammer, S., \& Pavelin, S. (2008). Factors influencing the quality of corporate environmental disclosure. Business Strategy and the Environment 17(2): 120-36. doi: https://doi.org/10.1002/bse.506.

Buonanno, G., Faverio, P., Pigni, F., Ravarini, A., Sciuto, D., \& Tagliavini, M. (2005). Factors affecting ERP system adoption: A comparative analysis between SMEs and large companies. Journal of Enterprise Information Management, 18(4), 384-426. doi: https://doi.org/10.1108/17410390510609572 
Siddique \& Sciulli | Environmental Initiatives and Disclosures by Large Companies

Cervantes, I. F., \& Brick, J. M. (2008). Empirical evaluation of raking ratio adjustments for nonresponse, section on survey research method' presented in Joint Statistical Meetings (pp. 2218-2224). Retrieved from https://www.researchgate.net/publication/267935744m

Chinda, T. (2016). Investigation of factors affecting a construction waste recycling decision. Civil Engineering and Environmental Systems, 33(3), 214-226. doi: https://doi.org/10.1080/10286608.2016.1161030

Cohen, M. (2008). Raking. In P. J. Lavrakas (Ed.), Encyclopaedia of survey research methods (pp. 672-674). Thousand Oaks, CA: SAGE Publications.

Comyns, B. (2016). Determinants of GHG reporting: An analysis of global oil and gas companies. Journal of Business Ethics, 136(2), 349-369. https://doi.org/10.1007/s10551-014-2517-9

Connelly, B. L., Certo, S. T., Ireland, R. D., \& Reutzel, C. R. (2011). Signaling Theory: A Review and Assessment. Journal of Management, 37(1), 39-67. doi: https://doi.org/10.1177/0149206310388419

Coppa, M., \& Sriramesh, K. (2013). Corporate social responsibility among SMEs in Italy. Public Relations Review, 39(1), 30-39. doi: https://doi.org/10.1016/j.pubrev.2012.09.009

Cormier, D \& Magnan M. (2015). The economic relevance of environmental disclosure and its impact on corporate legitimacy: an empirical investigation. Business Strategy and the Environment, 24(6), 431450. doi: https://doi.org/10.1002/bse.1829.

Commonwealth of Australia 2001, Corporation Act 2001, viewed 4 January 2019, $<$ http://www.austlii.edu.au/au/legis/cth/consol_act/ca2001172/>

Dashwood, H. S. (2013). Sustainable Development and Industry Self-Regulation: Developments in the Global Mining Sector. Business \& Society, 53(4), 551-582. doi: https://doi.org/10.1177/0007650313475997

da Silva Monteiro, S. M., \& Aibar-Guzmán, B. (2010). Determinants of environmental disclosure in the annual reports of large companies operating in Portugal. Corporate Social Responsibility and Environmental Management, 17(4), 185-204. doi: https://doi.org/10.1002/csr.197

de Villiers, C., Low, M., \& Samkin, G. (2014). The institutionalisation of mining company sustainability disclosures. Journal of Cleaner Production, 84, 51-58. doi:https://doi.org/10.1016/j.jclepro.2014.01.089

de Villiers, C., Low, M., \& Samkin, G. (2014). The institutionalisation of mining company sustainability disclosures. Journal of Cleaner Production, 84, 51-58. doi:https://doi.org/10.1016/j.jclepro.2014.01.089 https://doi.org/10.1016/j.jclepro.2014.01.089

de Villiers, C., \& van Staden, C. (2011). Shareholder Requirements for Compulsory Environmental Information in Annual Reports and on Websites. Australian Accounting Review, 21(4), 317-326. doi:doi:10.1111/j.1835-

2561.2011.00144.x https://doi.org/10.1111/j.1835-2561.2011.00144.x

Deegan, C., \& Rankin, M. (1997). The materiality of environmental information to users of annual reports. Accounting, Auditing \& Accountability Journal, 10(4), 562-583. https://doi.org/10.1108/09513579710367485 https://doi.org/10.1108/09513579710367485

Deng, X., Zheng, X., Su, X., Chan, F. T. S., Hu, Y., Sadiq, R., \& Deng, Y. (2014). An evidential game theory framework in multi-criteria decision-making process. Applied Mathematics and Computation, 244, 783-793. https://doi.org/10.1016/j.amc.2014.07.065 https://doi.org/10.1016/j.amc.2014.07.065

Dias, A., Rodrigues, L. L., Craig, R., \& Neves, M. E. (2019). Corporate social responsibility disclosure in small and medium-sized entities and large companies. Social Responsibility Journal, 15(2), 137-154. doi:doi:10.1108/SRJ-05-2017-0090 https://doi.org/10.1108/SRJ-05-2017-0090

Eleftheriadis, I. M., \& Anagnostopoulou, E. G. (2015). Relationship between Corporate Climate Change Disclosures and Firm Factors. Business Strategy and the 
Environment, 24(8), 780-789. doi:10.1002/bse.1845

https://doi.org/10.1002/bse.1845

Endrikat, J., Guenther, E., \& Hoppe, H. (2014). Making sense of conflicting empirical findings: A meta-analytic review of the relationship between corporate environmental and financial performance. European Management Journal, 32(5), 735-751. doi:https://doi.org/10.1016/j.emj.2013.12.004 https://doi.org/10.1016/j.emj.2013.12.004

Fernandez-Feijoo, B., Romero, S., \& Ruiz, S. (2014). Commitment to Corporate social responsibility measured through global reporting initiative reporting: factors affecting the behavior of companies. Journal of Cleaner Production, 81, 244254. doi:https://doi.org/10.1016/j.jclepro.2014.06.034 https://doi.org/10.1016/i.jclepro.2014.06.034

Galani, D., Gravas, E., \& Stavropoulos, A. (2012). Company Characteristics and Environmental Policy. Business Strategy and the Environment, 21(4), 236247. doi:doi:10.1002/bse.731 https://doi.org/10.1002/bse.731

Gallo, P. J., \& Christensen, L. J. (2011). Firm Size Matters: An Empirical Investigation of Organisational Size and Ownership on Sustainability-Related Behaviors. Business \& Society, 50(2), 315-349. doi:10.1177/0007650311398784 https://doi.org/10.1177/0007650311398784

Hahn, R., \& Kühnen, M. (2013). Determinants of sustainability reporting: a review of results, trends, theory, and opportunities in an expanding field of research. Journal of Cleaner Production, 59, 5-21. doi:https://doi.org/10.1016/j.jclepro.2013.07.005 https://doi.org/10.1016/j.jclepro.2013.07.005

Hassan, O. A. G. (2018). The impact of voluntary environmental disclosure on firm value: Does organisational visibility play a mediation role? Business Strategy and the Environment, 27(8), 1569-1582. doi:10.1002/bse.2217 https://doi.org/10.1002/bse.2217

James, H. S., \& Cohen, J. P. (2004). Does Ethics Training Neutralise the Incentives of the Prisoner's Dilemma? Evidence from a Classroom Experiment. Journal of Business Ethics, 50(1), 53-61. doi:10.1023/B:BUSI.0000020869.42655.f4 https://doi.org/10.1023/B:BUSI.0000020869.42655.f4

Katlon, G., \& Cervantes, I. F. (2003). Weighting Methods. Journal of Official Statistics, 19(2), 81-97.

Kemp, D., Owen, R., \& van de Graaff, S. (2012). Corporate social responsibility, mining and audit culture. Journal of Cleaner Production 24, 1-10. doi:https://doi.org/10.1016/j.jclepro.2011.11.002 https://doi.org/10.1016/j.jclepro.2011.11.002

KPMG (2017). The KPMG Survey of Corporate Responsibility Reporting 2017. Retrieved from https://assets.kpmg/content/dam/kpmg/xx/pdf/2017/10/kpmgsurvey-of-corporate-responsibility-reporting-2017.pdf

Lee, K.-H. (2017). Does Size Matter? Evaluating Corporate Environmental Disclosure in the Australian Mining and Metal Industry: A Combined Approach of Quantity and Quality Measurement. Business Strategy and the Environment, 26(2), 209-223. doi:10.1002/bse.1910 https://doi.org/10.1002/bse.1910

Lee, S., \& Klassen, R. D. (2016). Firms' response to climate change: The interplay of business uncertainty and organisational capabilities. Business Strategy and the Environment, 25(8), 577-592. https://doi.org/10.1002/bse.1890 https://doi.org/10.1002/bse.1890 
Siddique \& Sciulli | Environmental Initiatives and Disclosures by Large Companies

Liao, Z. (2018). Market Orientation and FIRMS' Environmental Innovation: The Moderating Role of Environmental Attitude. Business Strategy and the Environment, 27(1), 117-127. doi:10.1002/bse.1988 https://doi.org/10.1002/bse.1988

Litschka, M., Suske, M., \& Brandtweiner, R. (2011). Decision Criteria in Ethical Dilemma Situations: Empirical Examples from Austrian Managers. Journal of Business Ethics, 104(4), 473-484. doi:10.1007/s10551-011-0922-x https://doi.org/10.1007/s10551-011-0922-x

Lodhia, S. and Hess, N. (2014). Sustainability accounting and reporting in the mining industry: current literature and directions for future research. Journal of Cleaner Production, 84, 43-50. https://doi.org/10.1016/j.jclepro.2014.08.094

Lozano, R. (2007). Collaboration as a pathway for sustainability. Sustainable Development, 15(6), 370-381. doi:10.1002/sd.322 https://doi.org/10.1002/sd.322

Lyon, T. P., \& Shimshack, J. P. (2015). Environmental Disclosure: Evidence from Newsweek's Green Companies Rankings. Business \& Society, 54(5), 632-675. doi:10.1177/0007650312439701 https://doi.org/10.1177/0007650312439701

Michelon, G., Pilonato, S. \& Ricceri, R. (2015), CSR reporting practices and the quality of disclosure: An empirical analysis. Critical Perspectives on Accounting, 33, 59-78. doi.org/10.1016/j.cpa.2014.10.003. https://doi.org/10.1016/j.cpa.2014.10.003

Mudd, G. (2010). The environmental sustainability of mining in Australia: key megatrends and looming constraints. Resources Policy, 35(2), 98-115. https://doi.org/10.1016/j.resourpol.2009.12.001

Neshat, N., \& Amin-Naseri, M. R. (2015). Cleaner power generation through marketdriven generation expansion planning: An agent-based hybrid framework of game theory and Particle Swarm Optimization. Journal of Cleaner Production, 105, 206-217. https://doi.org/10.1016/j.jclepro.2014.10.083 https://doi.org/10.1016/j.jclepro.2014.10.083

Ostrom, E. (2000). Collective Action and the Evolution of Social Norms. The Journal of Economic Perspectives, 14(3), 137-158. https://doi.org/10.1257/jep.14.3.137

Patten, D.M. \& Zhao, N. (2014). Standalone CSR reporting by U.S. retail companies. Accounting Forum, 38(2), 132-144, doi: 10.1016/j.accfor.2014.01.002 https://doi.org/10.1016/j.accfor.2014.01.002

Perrini, F., Russo, A., \& Tencati, A. (2007). CSR Strategies of SMEs and Large Firms. Evidence from Italy. Journal of Business Ethics, 74(3), 285-300. doi:10.1007/s10551-006-9235-X https://doi.org/10.1007/s10551-006-9235-x

Prado-Lorenzo, J.-M., Gallego-Alvarez, I., \& Garcia-Sanchez, I. M. (2009). Stakeholder engagement and corporate social responsibility reporting: the ownership structure effect. Corporate Social Responsibility and Environmental Management, 16(2), 94-107. doi:doi:10.1002/csr.189 https://doi.org/10.1002/csr.189

Prasad, P., \& Elmes, M. (2005). In the Name of the Practical: Unearthing the Hegemony of Pragmatics in the Discourse of Environmental Management. Journal of Management Studies, 42(4), 845-867. doi:doi:10.1111/j.14676486.2005.00521.x https://doi.org/10.1111/j.1467-6486.2005.00521.x 
Qiu, Y., Shaukat, A., \& Tharyan, R. (2016). Environmental and social disclosures: Link with corporate financial performance. The British Accounting Review, 48(1), 102-116. doi:https://doi.org/10.1016/j.bar.2014.10.007 https://doi.org/10.1016/j.bar.2014.10.007

Ranängen, H., Zobel, T., \& Bergström, A. (2014). The merits of ISO 26000 for CSR development in the mining industry: a case study in the Zambian Copperbelt. Social Responsibility Journal, 10(3), 500-515. doi:10.1108/SRJ-05-2012-0110 https://doi.org/10.1108/SRJ-05-2012-0110

Richardson, A. J., \& Welker, M. (2001). Social disclosure, financial disclosure and the cost of equity capital. Accounting, Organisation and Society, 26(7), 597-616. doi:https://doi.org/10.1016/S0361-3682(01)00025-3 https://doi.org/10.1016/S0361-3682(01)00025-3

Robèrt, K.-H., \& Broman, G. (2017). Prisoners' dilemma misleads business and policy making. Journal of Cleaner Production, 140, 10-16. doi:https://doi.org/10.1016/j.jclepro.2016.08.069 https://doi.org/10.1016/j.jclepro.2016.08.069

Rover, S., Murcia, F. D.-R., \& De Souza Murcia, F. C. (2015). The determinants of social and environmental disclosure practices: The Brazilian case.

Environmental Quality Management, 25(1), 5-24.

https://doi.org/10.1002/tqem.21406

https://doi.org/10.1002/tqem.21406

Saha, A. and Akter, S. (2013). Relationship between environmental reporting in corporate annualreports and corporate profitability in Bangladesh, Global Conference on Business - Finance Proceedings, 8(1), pp. 75-86.

Scalet, S. (2006). Prisoner's Dilemmas, Cooperative Norms, and Codes of Business Ethics. Journal of Business Ethics, 65(4), 309-323. https://doi.org/10.1007/s10551-005-5356-X

Siddique, S. P., \& Sciulli, N. (2018). Sustainable development of small companies: Investors' perspectives. Business Strategy and the Environment, 27(8), 12581271. doi:10.1002/bse. 2073 https://doi.org/10.1002/bse.2073

Sözen, S., Orhon, D., Dinçer, H., Ateşok, G., Baştürkçü, H., Yalçın, T., Yağcı, N. (2017). Resource recovery as a sustainable perspective for the remediation of mining wastes: rehabilitation of the CMC mining waste site in Northern Cyprus. Bulletin of Engineering Geology and the Environment, 76(4), 15351547. doi:10.1007/s10064-017-1037-0 https://doi.org/10.1007/s10064-017-1037-0

Tanimoto, J. (2005). Environmental dilemma game to establish a sustainable society dealing with an emergent value system. Physica D: Nonlinear Phenomena, 200(1), 1-24. doi:https://doi.org/10.1016/j.physd.2004.09.016 https://doi.org/10.1016/j.physd.2004.09.016

Tagesson, T., Blank, V., Broberg, P., \& Collin, S.-O. (2009). What explains the extent and content of social and environmental disclosures on corporate websites: a study of social and environmental reporting in Swedish listed corporations. Corporate Social Responsibility and Environmental Management, 16(6), 352364. doi:doi:10.1002/csr.194 https://doi.org/10.1002/csr.194

Tilley, F. (2000). Small firm environmental ethics: How deep do they go? Business Ethics: a European Review, 9(1), 31-41. https://doi.org/10.1111/14678608.00167 https://doi.org/10.1111/1467-8608.00167 
Siddique \& Sciulli | Environmental Initiatives and Disclosures by Large Companies

Watkins, A., \& Hill, R. P. (2005). The Impact of Personal and Organisational Moral Philosophies on Marketing Exchange Relationships: A Simulation Using the Prisoner's Dilemma Game. Journal of Business Ethics, 62(3), 253-265. https://doi.org/10.1007/s10551-005-8714-9

White, M. D. (2009). Kantian Ethics and the Prisoners' Dilemma. Eastern Economic Journal, 35(2), 137-143. https://doi.org/10.1057/eej.2008.20

Woiceshyn, J. (2011). A Model for Ethical Decision Making in Business: Reasoning, Intuition, and Rational Moral Principles. Journal of Business Ethics, 104(3), 311-323.

https://doi.org/10.1007/s10551-011-0910-1

Wong, R. \& Millington, A. (2014). Corporate social disclosures: a user perspective on assurance. Accounting, Auditing and Accountability Journal, 27(5), pp. 863887. https://doi.org/10.1108/AAAJ-06-2013-1389

Xie, Y., Allen, C.J. , \& Ali, M. (2014). An integrated decision support system for ERP implementation in small and medium sized enterprises. Journal of Enterprise Information Management, 27(4), 358-384. doi:10.1108/JEIM-10-2012-0077 https://doi.org/10.1108/JEIM-10-2012-0077

Yadav, P. L., Han, S. H., \& Rho, J. J. (2016). Impact of Environmental Performance on Firm Value for Sustainable Investment: Evidence from Large US Firms.

Business Strategy and the Environment, 25(6), 402-420. doi:10.1002/bse.1883 https://doi.org/10.1002/bse.1883

Yao, S. and Yang, J. (2017), Geographical Distance and Environmental Information Disclosure: The Perspective of Public Pressure Transmission Efficiency. Asia Pacific Journal of Financial Studies, 46 (3), 445-462. doi:10.1111/ajfs.12176 https://doi.org/10.1111/ajfs.12176

York, J. G. (2009). Pragmatic Sustainability: Translating Environmental Ethics into Competitive Advantage. Journal of Business Ethics, 85(1), 97-109. doi:10.1007/s10551-008-9950-6 https://doi.org/10.1007/s10551-008-9950-6

Yu, J., Lo, C. W.-H., \& Li, P. H. Y. (2017). Organisational Visibility, Stakeholder Environmental Pressure and Corporate Environmental Responsiveness in China. Business Strategy and the Environment, 26(3), 371-384.

doi:doi:10.1002/bse.1923

https://doi.org/10.1002/bse.1923 